\title{
Research on Enterprise Information Construction Based on Computer Application Technology
}

\author{
LAI MIN ${ }^{1,}$, Liu Zheng Liang ${ }^{2, b}$ \\ ${ }^{1}$ Gannan Medical University, Gan zhou City, Jiangxi Province \\ ${ }^{2}$ Gannan Medical University, Gan zhou City, Jiangxi Province
}

Keywords: Computer Application Technology, Enterprise information, Countermeasure

\begin{abstract}
With the deepening of the technological level of our country, especially the computer technology is not interrupted to improve, information technology should become a broad synonym for the development of Chinese enterprises, computer, network technology and information processing technology has become a business in the operation, management, production and other links Indispensable tools, more rational application of computer technology and a more complete information technology has become an enterprise in the future development of the important task facing. This paper mainly analyzes the characteristics of computer network technology and enterprise information itself, and the survival and future problems of enterprises, hoping to provide guidance for enterprises in the future enterprise information practice. Business computer application technology and information technology an enterprise using computer technology, network technology and a series of modern technology, the depth of information resources through development and widespread use, and constantly improve the production, operation, management, efficiency and level of decision-making, thereby enhancing economic efficiency and competitiveness of the process.
\end{abstract}

\section{Theoretical Introduction of Enterprise Information}

Enterprise information is the business to business process (optimization) restructuring is based on a certain depth and breadth of the use of computer technology, network technology and database technology, all the information control and integrated management of production and operation activities, to achieve external enterprise sharing and effective use of information to improve economic efficiency and competitiveness in the market in a timely manner to provide accurate and effective data information and decision-making reference for business leaders.

In fact, many companies building sites for the development of enterprises, it is not too practical, the site can't be delivered customer's ideas, but can't reflect the existence of the problem, they can't help enterprises grasp market trends, which is detrimental to the development of enterprises. Meanwhile, due to the lack of communication between the customers, they can't know the needs of customers, the stability of market channels naturally can't be guaranteed. In order to deal with unexpected situations timely discovery, causing the entire logistics enterprise information transmission system is still in its original level and did not give full play to the advantages of the network information construction ${ }^{[1]}$.

Information technology is a process of advancing its development depends on three factors: First, the people on the deepening of understanding of their business activities, and second, the development of information technology, related to computing technology, network technology, artificial intelligence, etc. field; the third is on the business activities of IT penetration, the transformation ability and capacity that involves many technical systems. Enterprise information specific objectives are to optimize their business activities to make them more effective, its fundamental purpose is to improve the competitiveness of enterprises. Some companies have been gradually recognized market practice information utilization importance for the development of enterprises, but also to start building your own website, but the site post-maintenance and management work is relatively backward, many sites often long after the completion without page and updated. 


\section{The Significance of Enterprise Information Construction}

In the global knowledge-based economy and the rapid development of information technology today, information is the key factor in determining the success or failure, but also the business to achieve trans-regional, cross-ownership of an important prerequisite. The enterprise information construction can share resources, make use of modern information technology, research and development combined into one, effective development and utilization of information resources, seek to appropriate partners and projects to improve management, early out of the woods ${ }^{[2]}$. Fig. 1 shows the significance of enterprise information construction.

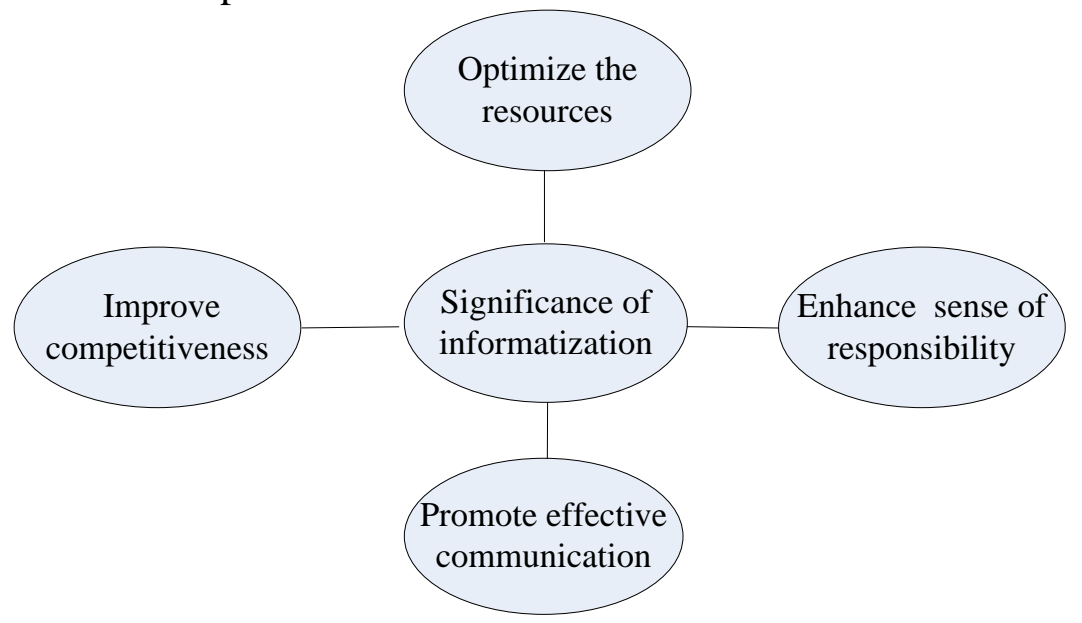

Fig. 1.The significance of enterprise information construction

Purpose computer application technology and information technology companies in order to give full play to the role of modern tools to provide more efficient and powerful support for enterprise development in order to improve overall core competitiveness, enterprise computer application technology and information technology for enterprises to timely grasp industry trends, market changes, which respond quickly to seize the opportunity to capture the market. Accelerate business process reengineering, organizational structure conducive to optimize, reduce costs and expand the scope of business competition, stimulate production, technological innovation, promote the progress of research and development projects to improve economic efficiency of enterprises to promote enterprise competition.

Business computer application technology and information technology to achieve clear responsibilities, clear job responsibilities and work to enhance people's sense of responsibility, reducing work Dodge, wrangling and other phenomena. Business computer application technology and information technology can achieve lower cost, greatly reduce office expenses, reduce management costs. Computer application technology has high speed, large capacity and other characteristics of the modern enterprise which can effectively guarantee the efficiency of enterprises, information technology can optimize the allocation of resources, improve enterprise management level, thereby enhancing the competitiveness of enterprises.

\section{The Enterprise Information Integration}

In order to solve the high-tech Enterprise Information integration problem, we have to find a practical way, that is, from the overall consideration of the enterprise information system, choose an appropriate integration platform, the enterprise organically integrate information silos, and businesses application Integration (EAI) is our best choice. EAI is the underlying structure by establishing contact across the entire heterogeneous enterprise systems, applications, data sources. There are many types of anti-virus software, so what kind of anti-virus software to choose a very important issue, this time people need to consider the performance of the computer and its applicability, only to use between each other to ensure that anti-virus software Give full play to their role, people usually need to maintain and anti-virus computer ${ }^{[3]}$. Fig.2 shows the EAI model design. 


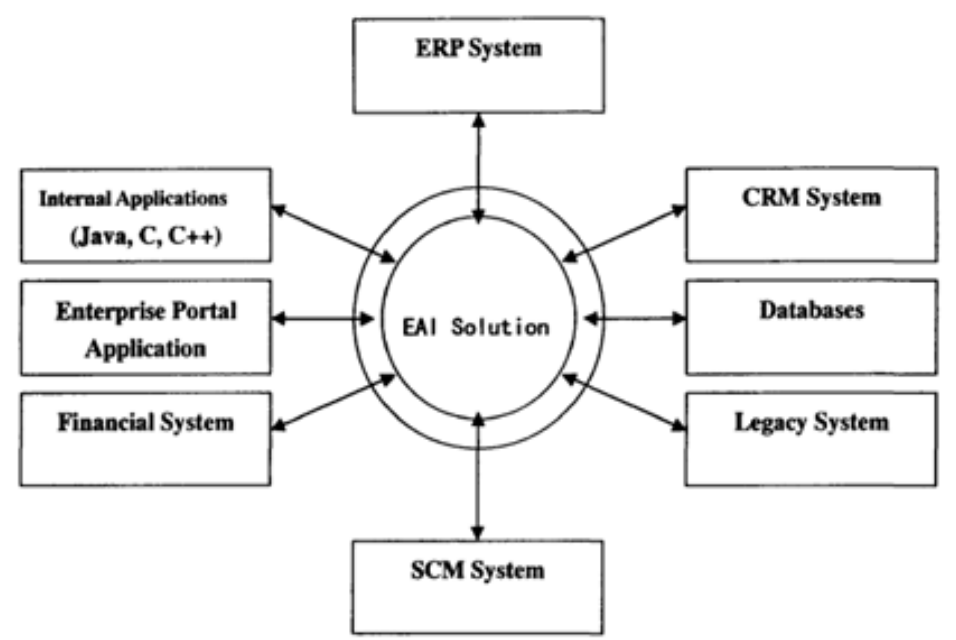

Fig. 2.The EAI model design

EAI is a new strategic business solution that leverage a common middleware (middleware) has been the integration of enterprise application software, packaged business applications as well as new code three functions. The integration refers to the integration of a user-oriented integration by providing a unified display interface to replace the original application system different graphical interfaces, thus hiding the background of different applications implementation details. Integrated logic interface as a conventional display integrated point to guide a user interactive operation, and communication between the operator and the corresponding software, and then the result produced by the different software components together, to avoid the user interface in different applications switching between, simplifying operations and improve efficiency.

Application integration requires integration points exist within the application code. Integrated office may simply just use the open application programming interface, and it may need to use additional code too complex segments to create a new access point. EAI business process integration is the most valuable part through the use of appropriate technology to standardize the information control, easy flow between input, output and transmission of information, sharing of information resources in different application systems business processes to optimize business overall business processes. Through the integration of business processes, can enable enterprises to enhance the sensitivity of the information, more quickly to market demand for information made to react and improve the competitiveness of enterprises ${ }^{[3]}$.

\section{Countermeasure for Enterprise Information Construction}

Chinese enterprises in the development process susceptible to the traditional concept of one-sided pursuit of economic efficiency of enterprises, while ignoring the enterprise management, enterprise management, the use of computer technology, enterprise information management, improve enterprise management level and economic, and computer information technology and information technology leadership in key decisions that affected the business concept of leadership, so we must change our philosophy of modern enterprise, the enterprise the production process, the use of computer technology and information technology to promote enterprise information management ${ }^{[4]}$.

A lot of computers are installed this firewall, it can be isolated between the virus and the computer, which is equivalent to a layer of protective film, through this layer of protective film can be achieved on the protection of the computer to avoid some of the virus, An isolation control technique. Firewall is now widely used in the technology, but also training a computer network system in a new great benefits of technological innovation. Antivirus software can be antivirus through the identification of computer viruses.

Encrypting the data information is a more proactive security defense. In fact, the encryption is to re-encode the information, so that the specific content of the information can be hidden, the information after encryption, its security and confidentiality can be effectively protected. The security work of the network is one of the most important aspects of enterprise information. The 
fundamental of information and standardization is to improve the work efficiency. If the technology is the prerequisite to ensure the security of the network, then the management is the most favorable guarantee of network security. Enterprise information is a systematic, integrated project, it is in the implementation process, there will be trivial links, which need to strengthen the organization of enterprises, strengthen the organization and leadership, from the policy to give strong support, and strengthen Information management, with a strong professional staff, supporting a series of measures ${ }^{[5]}$.

\section{Conclusions}

With the development of computer network and the continuous improvement of enterprise information level, enterprises gradually use computer information technology has been the trend of the trend, and the computer technology gradually into people's production and life of this situation, people need to constantly enrich themselves, continue to improve the management of the computer network system level, and to provide assistance to enterprises under the premise of enabling enterprises to multi-directional development. In the enterprise information management into the computer application technology, enterprise management has played a vital role. Especially in today's enterprise management from the traditional closed mode to the extension of the supply chain management, the application of computer application technology also from the single process or process control gradually developed to support the integration of enterprise supply chain management, which is the computer application technology and Enterprise information management continues to develop the inevitable result.

\section{References}

[1] E. J. Umbleetal. Enterprise resource planning: Implementation procedures and critical success factors [J].European Journal of Operational Research, 2005 (146):241-257.

[2] MANUELA SILVA, LUIZ MOUTINHO, ARNALDO COELHO, ALZIRAl MARQUES. Market orientation and performance: modelling a neural network [J].European Journal of Marketing Emerald Article, 2009, 43(3):421-437.

[3] Ing-Long Wu, Jian-Liand Chen. A hybrid performance measure system for e-business investments in high-tech manufacturing: An empirical study. Information \& Management, 2006, 43, 364-377.

[4] Wei Guo, Ke Chen. An empirical study on improving the manufacturing information index system of China [J].Proceedings of the 1st international conference[C].Australian, ICST, 2008:1-6.

[5] John J. Morris. The Impact of Enterprise Resource Planning (ERP) Systems on the Effectiveness of Internal Controls over Financial Reporting. Journal of information systems 2011(2):129-133 